\title{
ASSESSING DROUGHT CHARACTERISTICS OF MELAKA BASIN USING JOINT METEOROLOGICAL AND STREAMFLOW INDICES
}

(Date received: 11.11.2019/Date accepted: 17.03.2020)

\author{
Kee An Hong1, Jer Lang Hong1, Izihan Ibrahim² \\ ${ }^{1}$ Hong \& Associates ${ }^{2}$ International Islamic University
}

Email:keeanhong@yahoo.co.uk,jerlang.hong@taylors.edu.my,izihan@gmail.com

\begin{abstract}
In this study, drought occurrence in the Melaka basin has been assessed using the meteorological and hydrological drought indices. A continuous rainfall and streamflow data of 40 years were used for drought analysis. Results show that in terms of meteorological drought index, the severe drought occurred in 1986-1988. The streamflow drought index indicates that the extreme drought occurred in 1982-1984. Further analysis based on seasonal precipitation and streamflow data shows that there is no drought for 79\% of the time for the period 1960-2000 where there are hydrological records. For most of the dry and wet seasons, it is more likely that the frequency of occurrence of hydrological droughts only is higher than the frequency of occurrence of meteorological and hydrological droughts simultaneously or only meteorological droughts.
\end{abstract}

Keywords: hydrological drought meteorological drought, SDI, SPI, McKee, Joint assessment, MANN-Kendall, trend test, Sen

\subsection{INTRODUCTION}

Drought is a world wide natural disaster which has a severe consequence, that is, it affects every sector of the society and therefore there is a need to characterise or define the occurrence, severity and impact of a drought. Drought impact is relatively depending on the severity of drought developed in different stages of a drought event and different types of droughts are distinguished. A meteorological drought occurs when there is a deficit of precipitation in a region. An agricultural drought will occur when there is a lack of soil moisture due to lower than normal rainfall received. A hydrological drought is developed due to a deficit in water supply for drinking, irrigation, industrial and other needs.

Contrasting to other natural hazards such as floods that are typically restricted to relatively smaller regions and occurred over well defined time intervals, droughts are unpredictable and usually developed gradually and are identified only after they are well established [1, 2]. Studies [3] showed that droughts have dramatically increased in number and intensity in various parts of the world due to global climate change and increase in water demand for various sectors. As droughts have a far reaching and devastating impact on the planning and management of water resources, in recent years, much attention has been paid in understanding and evaluating the changing characteristics of droughts [4].

Drought can be assessed in terms of risk and severity through some form of indices. Various drought indices have been developed and some commonly used indices are shown in Table 1.

The hydrological and meteorological indices are mostly data intensive and need complex calculations which are time consuming in application. The SPI and SDI are found to be effective indices and they can be calculated with ease. The SPI
Table 1 Commonly used drought indices

\begin{tabular}{|l|l|l|}
\hline Drought type & Index name & References \\
\hline \multirow{5}{*}{ Meteorological } & $\begin{array}{l}\text { Standardised } \\
\text { precipitation index } \\
\text { (SPI) }\end{array}$ & McKee et al., [5] \\
\cline { 2 - 3 } & $\begin{array}{l}\text { Reconnaissance } \\
\text { drought index (RDI) }\end{array}$ & $\begin{array}{l}\text { Tsakiris and Vangelis } \\
\text { [6] }\end{array}$ \\
\hline \multirow{4}{*}{$\begin{array}{l}\text { Hydrological } \\
\text { drought }\end{array}$} & $\begin{array}{l}\text { Surface water supply } \\
\text { index (SWSI) }\end{array}$ & $\begin{array}{l}\text { Shafer and Dezman [7] } \\
\text { index (SDI) }\end{array}$ \\
\cline { 2 - 3 } & $\begin{array}{l}\text { Standardised } \\
\text { hydrological index } \\
\text { (SHI)_ }\end{array}$ & Sharma and Panu [8] \\
\hline \multirow{4}{*}{$\begin{array}{l}\text { Agricultural } \\
\text { drought }\end{array}$} & $\begin{array}{l}\text { Soil moisture deficit } \\
\text { index (SMDI) }\end{array}$ & $\begin{array}{l}\text { Narashiman and } \\
\text { Srinivasan [9] }\end{array}$ \\
\cline { 2 - 3 } & $\begin{array}{l}\text { Agricultural } \\
\text { reference index for } \\
\text { drought (ARID) }\end{array}$ & Woli et al., [10] \\
\hline
\end{tabular}

method derived by McKee [5] needs only precipitation data and is able to describe drought severity under various climatic conditions. It has been widely adopted in meteorological drought studies. The SDI developed by Nalbantis [1] is normally used for deriving drought index using streamflow data. It can be applied to any time scale.

In this study, we used the SPI and SDI methods to derive the drought indices of Melaka basin as a case study. Furthermore, using the joint SPI and SDI indices, this study assessed the drought events and their distributions of Melaka basin accurately. The drought trends and the frequency of drought occurrence are also analysed using trend test and the derivation of drought occurrence frequency. 


\subsection{STUDY AREA}

\subsection{The Melaka Basin}

The Sg Melaka basin is shown in Figure 1. The basin area is 350 $\mathrm{km}^{2}$. The maximum breadth and width of the basin are $26 \mathrm{~km}$ and $14 \mathrm{~km}$. The basin is of low lying and undulating hills in the south and mountainous country in the north border. A small area in the south is below $15 \mathrm{~m}$ contour line.

The main river Sg Melaka and its major tributary, the $\mathrm{Sg}$ Batang Melaka rise to the hill in the north.The two rivers meander through low lying and undulating land on their way to the sea. The low-lying area is cultivated with palm oil whilst the upper basin is covered with lallang and forest. The soil cover of the basin is basically coarse and sandy clay.

\subsection{Hydrological Data}

The Melaka basin was chosen as a case study as there are three rainfall stations quite evenly distributed in the basin with long and rather continuous records. In this context, the mean basin rainfall can be estimated with accuracy. There is a streamflow record of 40 years although intermittent missing records exist. Years with complete records are available and can be used for rainfall runoff modelling. The evaporation station is located at Melaka Airport and the potential monthly evaporation values have been estimated [11]. Details of the data available are listed in Table 2. The data were examined carefully for consistency.

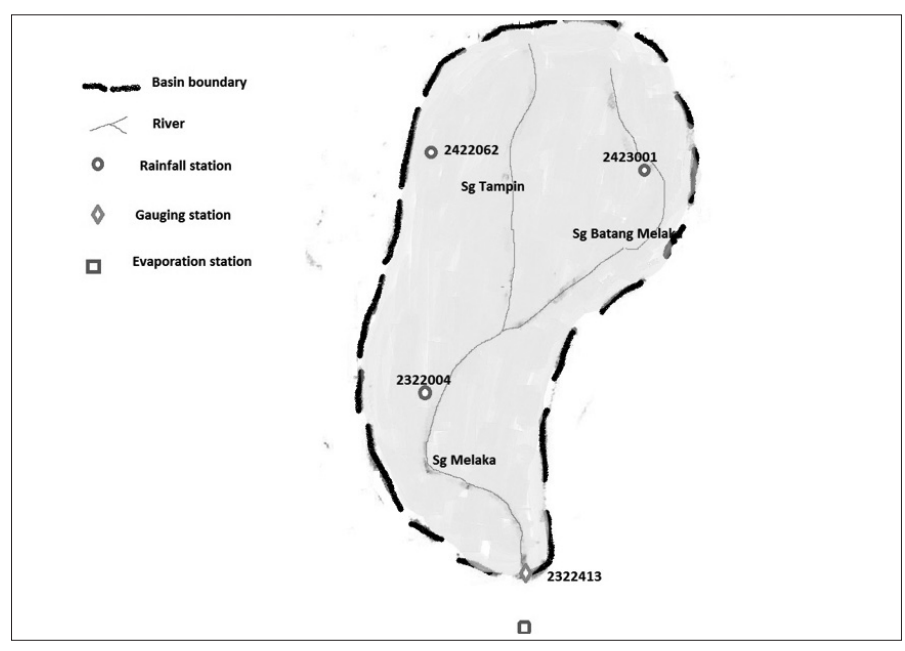

Figure 1 The Melaka basin

Table 2 Hydrological data of Melaka basin

\begin{tabular}{|l|l|l|l|}
\hline \multirow{4}{*}{ Rainfall } & Station name & Station ID & Period of recods \\
\cline { 2 - 4 } & St. Thomas School & 2422062 & 1948 - to date \\
\cline { 2 - 4 } & Ladang Tebolang & 2423001 & 1953 - to date \\
\cline { 2 - 4 } & JKR Alor Gajah & 2322004 & 1948 - to date \\
\hline Streamflow & $\begin{array}{l}\text { Sg Melaka at } \\
\text { Pantai Belimbing }\end{array}$ & 2322413 & $1960-2000$ \\
\hline Evaporation & Melaka Airport & 0210 & 1960 - to date \\
\hline
\end{tabular}

\subsection{METHODOLOGY}

\subsection{Standardised Precipitation Index (SPI)}

The SPI, proposed by McKee [5], is widely used to evaluate the severity of meteorological droughts. The method uses cumulative precipitation at various time scales to assess the distribution of drought intensity. The continuous monthly precipitation
$P_{i j}$ is added sequentially according to the time scale under consideration, $\mathrm{k}$. The cumulative precipitation, $R_{i k}$ of the ith year and at $\mathrm{k}$ time scale can be calculated as:

$$
R_{i k}=\sum_{j=1}^{3 k} P_{i j} \quad, \mathrm{i}=1,2,3 \ldots . ., \mathrm{j}=1,2,3, \ldots \ldots .12, \mathrm{k}=1,2,3,4
$$

Where $\mathrm{i}$ is the year under consideration and $\mathrm{j}$ is the month. The values of $\mathrm{k}=1, \mathrm{k}=2, \mathrm{k}=3, \mathrm{k}=4$ denote the periods of October to December, January to March, April to June, July to September respectively. The SPI of the ith year at time scale $\mathrm{k}$ defined by cumulative precipitation $R_{i k}$ is:

$$
S P I_{i k}=\frac{R_{i k}-\overline{R_{k}}}{s_{R k}} \quad \mathrm{i}=1,2,3 \ldots \ldots, \mathrm{k}=1,2,3,4
$$

Where $\overline{R_{k}}$ and $s_{R k}$ are the average cumulative precipitation and standard deviation at time scale $\mathrm{k}$ respectively. Gamma distribution is normally used to transform the distribution of precipitation data before they are used in the SPI calculation. For the two parameter log- normal distribution function, the natural $\log$ of the precipitation data is used and the SPI is calculated as:

$$
S P I_{i k}=\frac{w_{i k}-\overline{w_{k}}}{s_{w k}}, \mathrm{i}=1,2,3, \ldots \ldots, \mathrm{k}=1,2,3,4
$$

Where $S P I_{i k}$ is the SPI value at the cumulative precipitation time scale $\mathrm{k}, w_{i k}$ is the natural log of the cumulative precipitation, $\overline{W_{k}}$ is the average value and $S_{w k}$ is the standard deviation.

The definition and classification of SPI by McKee as listed in Table 3 are adopted for this study.

\section{Table 3 Classification of SPI and SDI values}

\begin{tabular}{|l|l|}
\hline Condition & Criterion \\
\hline Non drought & $-1.0<\mathrm{SPI}, \mathrm{SDI}<=1.0$ \\
\hline Moderate drought & $-1.5<\mathrm{SPI}, \mathrm{SDI}<=-1.0$ \\
\hline Severe drought & $-2.0<\mathrm{SPI}, \mathrm{SDI}<=-1.5$ \\
\hline Extreme drought & $\mathrm{SPI}, \mathrm{SDI}<-2.0$ \\
\hline
\end{tabular}

\subsection{Streamflow Drought Index}

Nalbantis [1] proposed the SDI to study the distribution and variation of drought severity. The method is based on the cumulative streamflow data at various time scales. The approach in SDI calculation is the same as that of SPI. The SDI values were calculated using this method. For streamflow drought classification, we use the definition of Al-Faraj [11] (see Table 3).

\subsection{Mann Kendall Trend Test}

The Mann Kendall trend test was devised by Mann [12] and Kendall [13] and is commonly used in the analysis of trends in meteorological and hydrological droughts. The test identifies whether significant trends exist using the differences in consecutive data. The results are not affected by extreme values or missing values in the data sequence. For a time series $\mathrm{t} 1, \mathrm{t} 2$, $\mathrm{t} 3 \ldots \mathrm{tn}$ and the corresponding data sequence $\mathrm{x} 1, \mathrm{x} 2, \mathrm{x} 3, \ldots \mathrm{xn}$ where $\mathrm{n}$ is the number of data points, the Mann Kendall statistics, $\mathrm{S}$, is defined as:

$$
\begin{array}{cc}
S=\sum_{i=1}^{n-1} \sum_{j=i+1}^{n} \operatorname{Sign}\left(X_{j}-X_{i}\right), \operatorname{Sign}\left(X_{j}-X_{i}\right) \\
+1, X_{j}-X_{i}>0 \\
=\quad 0, X_{j}-X_{i}=0 \\
-1, X_{j}-X_{i}<0
\end{array}
$$

For $n>=10$, the probability distribution of $S$ approximately fits a normal distribution with an average of 0 , The variance is defined as:

$$
\operatorname{Var}(S)=\frac{n(n-1)(2 n+5)}{18}
$$


The existence of significant trends in the time series data is determined by the $\mathrm{Z}$ value, where:

$$
\begin{array}{r}
\quad \frac{s-1}{\sqrt{\operatorname{Vae}(S)}}, \quad S>0 \\
\mathrm{Z}=\quad, \mathrm{S}=0 \\
\frac{S+1}{\sqrt{\operatorname{Var}(S)}} \quad \mathrm{S}<0
\end{array}
$$

Positive and negative $\mathrm{Z}$ values represent increasing and decreasing trends. The $\mathrm{Z}$ values are then subjected to further significant tests. In this study, the level of significance is set at $\alpha=0.05$. If $|Z|>=1.96$, the time series data show a significant trend and if $|Z|<1.96$, there is no significant trend.

\subsection{Theil-Sen Estimator}

The Theil -Sen estimator was proposed by Theil [14] and Sen [15] to calculate the trend slope, $\beta$ which is defined as:

$$
\beta=\operatorname{Median}\left[\frac{x_{j}-x_{i}}{j-i}\right], i<j
$$

Where $\beta$ is the median of the slopes of all lines through pairs of points in the time series data, and $x i$ and $x j$ are the corresponding data at time $\mathrm{I}$ and $\mathrm{j}$. The regression line was calculated after the trend slope was determined.

$$
\begin{aligned}
& \mathrm{X}(\mathrm{t})=\beta t+C \\
& \mathrm{X}(\mathrm{t})=x_{1} \sim x_{n}, \mathrm{t}=1 \sim \mathrm{n}
\end{aligned}
$$

Substituting the median of precipitation and flow data, $(\mathrm{x} 1, \mathrm{x} 2, \mathrm{x} 3 \ldots \ldots . . \mathrm{xn})$ and time t into equation (8), gives the constant $\mathrm{C}$. Positive and negative $\beta$ values represent increasing and decreasing trends respectively.

\subsection{RESULTS}

\subsection{Infilling of Streamflow and Rainfall Data}

The missing streamflow data of Sg Melaka were infilled using the HEC-HMS rainfall runoff model [16] so that a continuous record of 40 years of daily data are available for this analysis.

More complete rainfall data are available, gaps with a few days or a month of missing data were infilled using records of adjacent stations.

\subsection{Meteorological Droughts}

The annual SPI results (October to September) of the three rainfall stations in the Melaka basin were used to assess the meteorological droughts. Figure 2 is a graphical summary of the drought occurrence of the three rainfall stations from 1960-2000, a period of 40 years. In general, the trend of SPI are quite consistent for the rainfall stations except droughts of Ladang Tebolang are more severe in the early years than the other two stations. No significant droughts are recorded in the period 1960-1973 except Ladang Tebolang where the SPI is -2.15 in 1964-65. Alor Gajah recorded SPI values of -4.36 in 1974 and -1.3 in 1977. The highest SPI of St Thomas school are -1.6 in $1977,-1.42$ in $1988-3.15$ in 1989 and -2.07 in 1990 . There are no major droughts after 1990 except the SPI of -1.5 for Ladang Tebolang. Overall, The severe droght occurred in 1974-1977, 1986-1990.

Trend tests show that there is positive trend for JKR Alor Gajah (positive Z) and no trend for St. Thomas School $(Z=0)$ long term SPI but there is a negative trend (negative $Z$ ) for Ladang Tebolang (Figures 3 and 4 and 5). Trend test results are summarised in Table 4.

The Sen estimator results show that the drought trend slopes $(\beta)$ are positive for JKR Alor Gajah and 0 for St Thomas School and negative for Ladang Tebolang. The overall results indicate that there is no tendency of increasing droughts in recent years. The $\mathrm{C}$ value in Table 4 is the constant for the trend line.

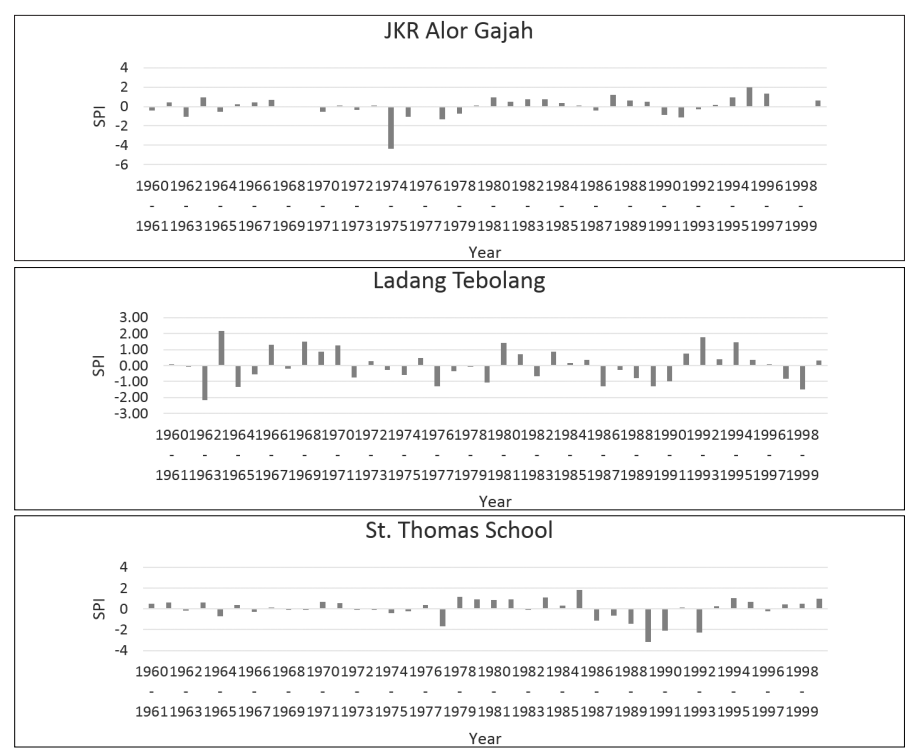

Figure 2 SPI of rainfall stations in Melaka basin

Table 4 Trend test results for SPI

\begin{tabular}{|l|l|l|l|}
\hline Rainfall station & $\mathrm{Z}$ & $\beta$ & $\mathrm{C}$ \\
\hline JKR Alor Gajah & 1.55 & 0.018 & -0.23 \\
\hline St Thomas School & 0 & 0 & 0.18 \\
\hline Ladang Tebolang & -0.43 & -0.008 & 0.08 \\
\hline
\end{tabular}

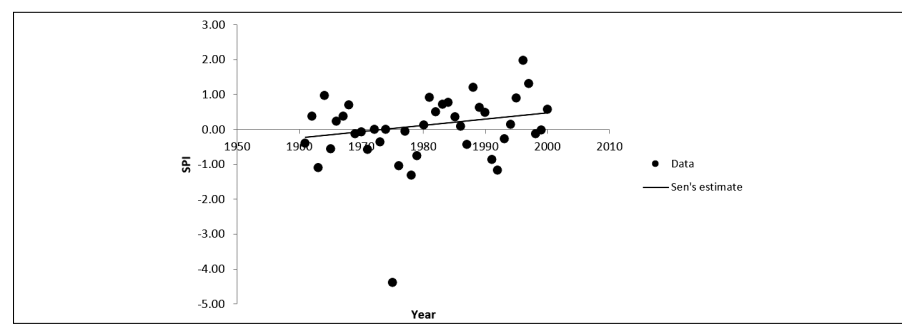

Figure 3 Trend test results for SPI (October to September), of JKR Alor Gajah

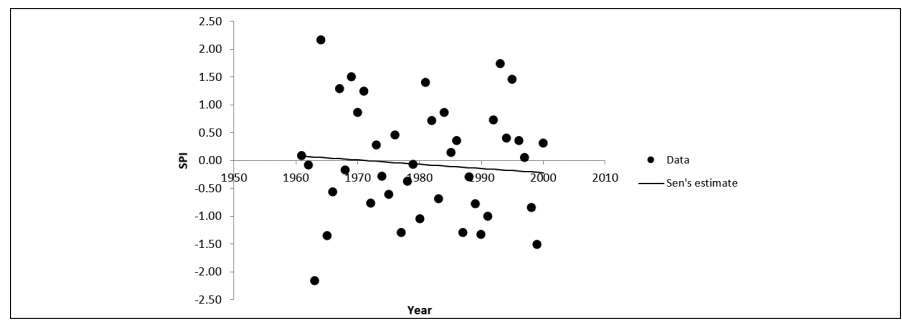

Figure 4 Trend test results for SPI (October to September), of Ladang Tebolang

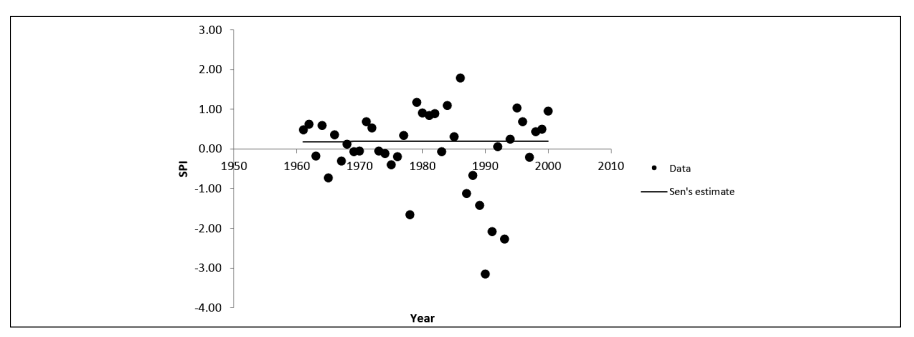

Figure 5 Trend test results for SPI (October to September), of St Thomas School 


\subsection{Hydrological Droughts}

In this section, the annual SDI results from the gauging station are presented to evaluate the general SDI trends. Figure 6 shows the SDI results for Sg Melaka at gauging station.

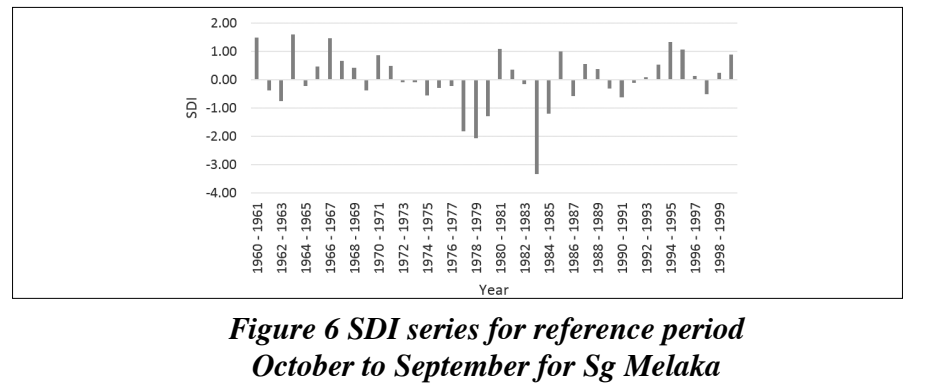

Two extreme drought events were noted, 1977-1980 and 1982-1984 with highest SDI of -2.07 and -3.34 respectively. Only mild droughts were recorded before 1977 . There were few moderate droughts after 1985.

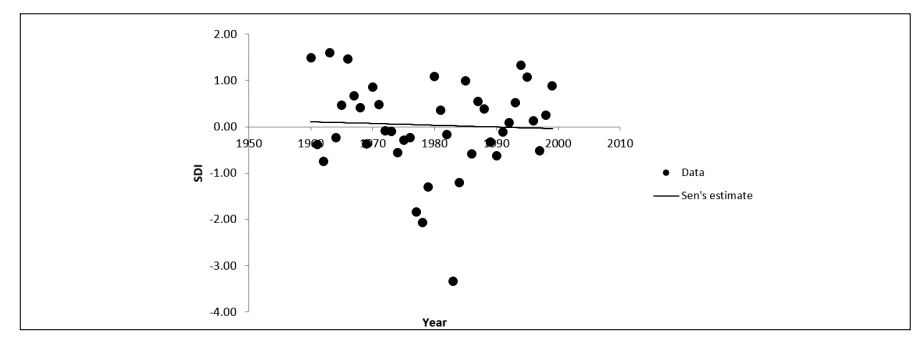

Figure 7 Trend test results for SDI

(October to September), of Sg Melaka

Table 5 Trend test results for SDI, Sg Melaka

\begin{tabular}{|l|l|l|l|}
\hline Gauging station & $\mathrm{Z}$ & $\beta$ & $\mathrm{C}$ \\
\hline Sg Melaka & -0.2 & -0.04 & 0.11 \\
\hline
\end{tabular}

The trend results indicate that there is a slight decrease in SDI for the Melaka river. There are no major droughts after 1986.

\subsection{Joint Meteorological and Hydrological Analysis}

The two drought indices, namely SPI and SDI, were separately calculated for different seasons and the results of SDI were analysed in conjunction with SPI to distinguish the time of occurrence of the respective indices and their relationships. As Sg Melaka is dominated by the monsoon seasons, there are two distinguished wet seasons, (October to December, April to June) and two dry seasons (January to March and July to September). Therefore, SDI and SPI were derived separately for the four seasons with a 3 month time scale to assess the impact of meteorological and hydrological changes on droughts.

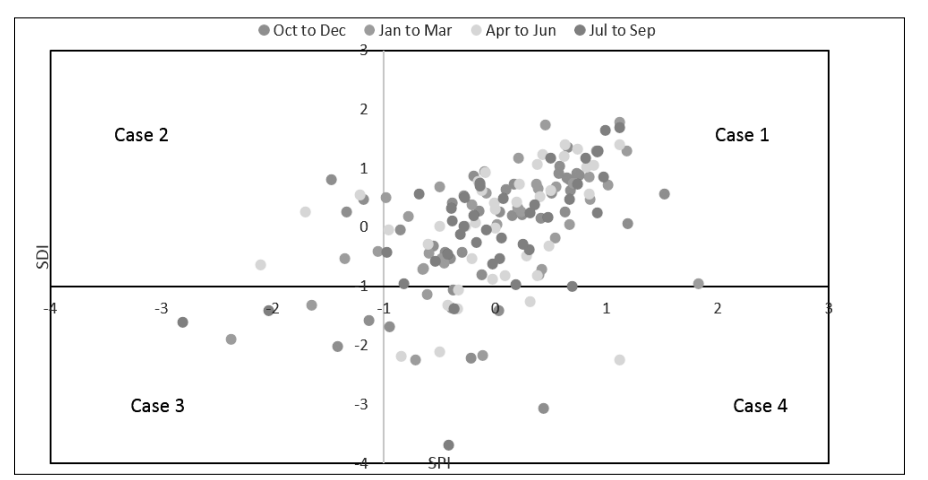

Figure 8 Joint assessment (SDI-SPI) for hydrometeorogical drought In Melaka basin
The drought classification scheme says that SDI ang SPI greater than -1 imply that no drought occurs. When the X-axis and Y-axis of the Cartesian system are used to represent the SPI and SDI, drought events can be divided into 4 cases. The first quadrant is case 1 . where both meteorological and hydrological droughts are absent. The second quadrant represents case 2 , in which meteorological droughts but not hydrological droughts occur. The third quadrant is case 3 , where there are both meteorological and hydrological droughts. The fourth quadrant represents case 4 , in which only hydrological droughts occur. Droughts usually starts with case 2 , with only meteorological droughts, as precipitation continues to decrease, surface water shortages occur and case 3 begins. When it rains again, meteorological droughts are alleviated and the area goes back to normal condition or even becomes relatively wet. However, hydrological drought cannot be reversed immediately (case 4). When the amount of precipitation is sufficient for the area to return to normal condition, case 4 will return to case 1. The four quadrant SDI-SPI joint assessment for the meterological hydrological events is shown in Figure 8. The distribution of drought events classified into four cases reveals that most drought events fall into case 4 and case 1 . The annual frequency of occurrence of the drought events are calculated and shown in Table 6.

Table 6 Frequency of drought events, Melaka basin, in percent

\begin{tabular}{|l|l|l|l|}
\hline Case 1 & Case 2 & Case 3 & Case 4 \\
\hline 79.4 & 5 & 3.8 & 11.9 \\
\hline
\end{tabular}

The average frequency of no droughts is $79.4 \%$, while the existence of both the meteorological drought and hydrological drought is $3.8 \%$. The frequency of drought events in the wet and dry seasons for the 4 cases are shown in Table 7.

Table 7 Frequency of droughts in the wet and dry seasons

\begin{tabular}{|l|l|l|}
\hline Season & Drought case & Frequency of occurrence \% \\
\hline \multirow{4}{*}{$\begin{array}{l}\text { October to } \\
\text { December }\end{array}$} & 1 & 75 \\
\cline { 2 - 3 } & 2 & 7.5 \\
\cline { 2 - 3 } & 4 & 5 \\
\hline \multirow{4}{*}{ January to } & 1 & 12.5 \\
\cline { 2 - 3 } March & 2 & 80 \\
\cline { 2 - 3 } & 4 & 5 \\
\hline \multirow{4}{*}{$\begin{array}{l}\text { April to } \\
\text { June }\end{array}$} & 2 & 5 \\
\cline { 2 - 3 } & 3 & 10 \\
\cline { 2 - 3 } & 4 & 75 \\
\hline \multirow{4}{*}{$\begin{array}{l}\text { July to } \\
\text { September }\end{array}$} & 1 & 7.5 \\
\cline { 2 - 3 } & 2 & 0 \\
\cline { 2 - 3 } & 4 & 17.5 \\
\hline
\end{tabular}

For seasonal droughts, the highest frequency of occurrence is still for case 1 (no drought), the second highest is case 4 where there is only hydrological drought. The joint SDI SPI analysis shows that case 4 is more likely to occur than case 2 or case 3 . The joint SDI-SPI assessment of drought conditions gives a clearer picture on the occurrence and distribution of meteorological and hydrological droughts and the actual drought situation. 


\section{ASSESSING DROUGHT CHARACTERISTICS OF MELAKA BASIN USING JOINT METEOROLOGICAL AND STREAMFLOW INDICES}

\subsection{CONCLUSION}

In this study, 40 years of concurrent rainfall and streamflow data of Melaka river basin have been used to derive the standard precipitation index (SPI) and streamflow drought index (SDI). Results of SPI (full year) show that severe meteorological droughts generally occurred in 1974-1977 and 1986-1988. The overall results indicate that there is no tendency of increasing droughts in recent years based on SPI analysis.

From SDI analysis, two extreme drought events were noted, 1977-1980 and 1982-1984 with highest SDI of -2.07 and -3.34 respectively. Only mild droughts were recorded before 1977 . There were few moderate droughts after 1985.

The two drought indices, namely SPI and SDI, were separately calculated for different seasons and the results of SDI were analysed in conjunction with SPI to distinguish the time of occurrence of the respective indices and their relationships. As Sg Melaka is dominated by the monsoon seasons, there are two distinguished wet seasons, (October to December, April to June) and two dry seasons (January to March and July to September). Therefore, SDI and SPI were derived separately for the four seasons with a 3 month time scale to assess the impact of meteorological and hydrological changes on droughts. For seasonal droughts, the highest frequency of occurrence is where there is no drought events, the second highest is where there is only hydrological drought.. The joint SDISPI assessment of drought conditions gives a clearer picture on the occurrence and distribution of hydrological and hydrological droughts and the actual drought situation.

\subsection{ACKNOWLEDGEMENT}

The permission of Drainage and Irrigation Department to use the data for this study is gratefully acknowledged.

\section{REFERENCES}

[1] Nalbantis I, Tsakiris G.(2009) Assessment of hydrological drought revisited, water Resource Manage 23(5)

[2] Vicente-Serrano S.M., Lopez Moreno J.L. Beguneria S. Lorenzo-Lacunz J.Azorin-Molima C. ,Tejeda E(2012) Accurate comparison of a streamflow drought index .J. Hydrol. Eng. 17(2)
[3] Bates B., Kundzewicz ZW, Wu S., Palutikof J [2008], Climate change and water Paper of IPCC

[4] Zhang Q., Xiao M., Singh V.P., Chen X., [2013] Couplas based risk evaluation of droughts across the Pearl river basin ChinaTheor Appl. Climatol. 111(1)

[5] McKee T.B. Dosken N.J. ,Kleist J [1993], The relationship of drought frequency and duration in time scales, American meteorological society

[6] Tsakiris G., Vangelis H[2005] Establishing a drought index incoroperating evaporation ,European water resources association, 9-10

[7] Shafer B. A..Dezman L. E. [1982] Development of a water supply index to assess the drought severity conditions in snowpack runoff area In western snow conference Fort Collins

[8] Sharma T., Panu U., [2010], Analytical procedure for weekly drought : a case study of Canadian rivers Hydrolgical science journal 55

[9] Narashiman E., Srinivasam R., [2005] Development and evaluation of soil moisture deficit index (SMDI) and evaporation deficit index (ETDI) for agricultural drought monitoring, Agricultural and forest meteorology 133

[10] Woli P.,Jones J.,Ingram K.T.,Praise C.W., [2012] Agricultural reference for droughts (ARID) Agronomy journal 104

[11] Al=Faraj F.A.M.,Scholz M, Tigkas D [2014] sensitivity of surface runoff to drought and climate change, application for shared river basin Water 6

[12] Mann H. B. [1945] Nonparametric test against trend, Econometrica 13

[13] Kendall M. G. [1975] Rank correlation methods Nafners New York

[14] Theil H [1950] A rank invariant method of linear and polynomial regression analysis ,proceedings of koninalikjke nerdalandise academie van weienschapton A 451

[15] Sen P.K. [1968] Estimates of the regression coefficient based on Kendall,s tau Journal of the American statistical association 63

[16] Kee An Hong, Jer lang Hong, Izihan Ibrahim and Nur Wajihah [2019] Infilling missing streamflow data using HEC-HMS, unpublished

\section{PROFILES}

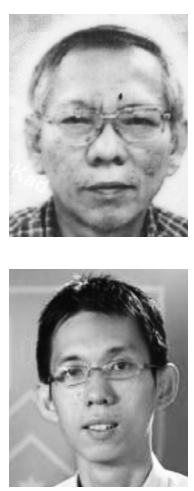

HONG KEE AN is presently a consultant in hydrology and water resources and he worked as a hydrologist, water resources planner and modeler for various water supply projects in Malaysia. He received his B. Sc. degree in Agricultural Engineering from National Taiwan University in 1971 and the M. Eng. degree in Water Science from Asian Institute of Technology in 1973. He is the author of several papers published in the journal and bulletins of the Institution of Engineers, Malaysia and Malaysian Water Work Association and the books "A Guide to Flood and Yield Estimation" and "Hydrlogical Analysis and Design: An approach based on Malaysian Rainfall and Runoff". He is a Fellow of the Institution of Engineers, Malaysia and is listed in Who's Who in Engineering published by the American Association of Engineering Societies. Email address: keeanhong@yahoo.co.uk

DAVID HONG JER LANG is currently a lecturer of Taylor's University, Malaysia. He received his B. Sc degree in computer science from Nottingham University in 2005 and the Ph. D. degree from Monash University in 2010. He is author and co-author of several Association for Computing Machinery/Institution of Electrical and Electronic Engineers (ACM/IEEE) conference papers and is also the author of several papers in automatic wrapper design published in computer science journals and is the co-author of the book "Hydrological Analysis and Design: An approach based on Malaysian Rainfall and Runoff”. David Hong is listed in Who's Who in the World. Email address: jerlang.hong@taylors.edu.my

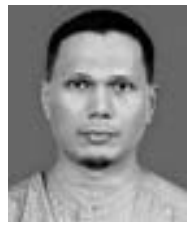

IZIHAN BIN IBRAHIM is a civil Engineering graduate and he obtained a Master's degree from Imperial College UK in Engineering Hydrology He was a lecturer of university Kebangsaan for 3 years before he joined HYDEC, a consulting Engineering firm. Izihhzn is presently a lecturer in International Islamic University and he is also a Diector of Rho 1, a consulting firm in Hydrology and hydraulics. Email address: izihan@gmail. com, izihan@iium.edu.my 